\title{
A Statistical Analysis of Consumer's Willingness to Pay for Improved Water Supply System: A Study of some Villages of Uttar Pradesh, India
}

\author{
A. Deepak Chauhan, B. Dhananjai Rai, C. MD Zafar Ali Khan, D. Naveen Patel
}

\begin{abstract}
We all are aware about the utility of water in our life, we may live without other things but life without water is beyond expectation. But a large number of countries specially developing ones are still unable to fulfill the daily water needs of their individuals. The Condition further becomes worse in the rural areas. It is highly appreciated that government is working to improve water supply system. In this study we are trying to figure out whether people of rural areas of Uttar Pradesh state of India are satisfied with water system provided by government or not. This study further concentrates on a survey, which tries to figure out whether rural habitants are willing to pay for improved water supply system or not. This paper is generally based upon the Contingent Valuation Survey in order to determine the preferences of households for improved water facilities along with the amount they are willing to pay as well as Willingness to contribute in form of manual power so that people gets basic need of life in more effective way and also some amount of revenue is generated for the government authorities so that they can work in more efficient manner. The present study will help in demonstrating the real scenario of the water system in Bijnor district of Uttar Pradesh of India. Data is collected through surveys (open-ended questionnaire) and processed by software IBM SPSS Statistics using factor analysis tool. Results of the study will be advantageous in order to fix some amount of water supply charges as per people Willingness.
\end{abstract}

Index Terms - Contingent Valuation Survey, Rural background, Developing Nations, Water Supply System

Manuscript revised on September 15, 2019 and published on October 10, 2019

A. Deepak Chauhan former student of M.Tech in Department of Civil Engineering at BIET, Jhansi.

B. Dhananjai Rai former student of M.Tech in Department of Civil Engineering at BIET, Jhansi.

C. MD. Zafar Ali Khan guest lecturer in Department of Civil Engineering at Government Polytechnic College, Gonda.

D. Naveen Patel former student of M.Tech in Department of Civil Engineering at NIT, Agartala.

\section{INTRODUCTION}

Basic need of one's life is Water. Every organism including Human being, plants and animals need this resource to survive. Apart from domestic purposes like drinking, cooking, washing etc. water has many other essential usages like in agricultural purposes, industrial purposes, hydropower generation and maintenance of healthy ecosystem [1]. But disappointingly developing countries are not able to provide clean potable water to a majority of population, resulting in severe health ailments or even death, approximately $3.1 \%$ death are related to consumption of contaminated water [2]. Some health impact are immediate while some are noticed over time, these include illness related to stomach, intestines, vomiting, diarrhea, cramps and many other harmful effects [3]. World Health Organization indicates that nearly $80 \%$ diseases are somewhere and somehow related to water contamination and a notable number of countries are not able to fulfill the standards laid by WHO for drinking water [4].The most important need of present time is to provide potable water, sanitation, neat and clean environment to the rural population as they suffer from a lot of water related health issues [5]. People belonging to rural areas deprive of proper water supply system hence mostly hinge on unconventional system of water sources such as dug wells, hand pump etc. and lack of awareness further leads to making the problem more critical. Provision of clean water is crucial to enhance the health of individual and to lower down the cases of diseases due to contaminated water. The problem is not only limited to water quality but also related to its quantity. Rural habitants tend to extract water from ground for satisfying their domestic and agricultural needs which often causes deterioration of ground water table. There are mainly two reasons provided by experts on water problem, one is natural mode and other one is artificial. Natural mode consists of disasters in form of flood, earthquake, landslides, Tsunami etc. whereas artificial mode is created by humans and is considered as the major cause of water pollution. It includes industrialization, urbanization and entry of waste particle generated 
by human activities into water sources which pollutes both surface and groundwater [6]. Water related problems including both quality and quantity, is the biggest threat in the world and unfortunately India is also among one of its victim. A report published by Water Aid in 2016 ranked India as one of the worst nation in world with a large population of people without potable water. Approximately 76 million people in India do not have any reliable source of safe water and condition is getting worst day by day [7]. In a research conducted on world water scarcity, India is listed as a country which will be having resource less than threshold level of $1500 \mathrm{~m}^{3} /$ capita/year by the year 2030 [8]. According to an article published on water scarcity, 4 billion people which is approximately two- third of world population encounter severe water scarcity at least one month of the year, and unfortunately out of these 4 billion people, 1 billion live in India only. These sorts of statistics show the, actual condition of the world's second most populous nation [9]. A report submitted by Central Ground Water Board (CGWB) and committee on restructuring the Central Water Commission (CWC), in 2016 states that if current demand pattern continues then, by 2030 half of the demand will remain unfelt (cwc report). In addition to that, waater scarcity is expected to become more severe as India's growth rate is $1.19 \%$, so expected to reach 1.7 billion by 2050 [10]. The Asian Development Bank has forecasted that India will have nearly $50 \%$ water deficit by 2030 .

This water problem become further worse in rural areas, data collected from Ministry of Drinking Water and Sanitation shows that 19,000 villages in India still do not have safe water supply. In this context, Indian Government's first effective role in rural drinking water supply started in 1972-1973 with the launch of Accelerated Rural Water Supply Program (ARWSP) for assisting States/Union Territories to accelerate the coverage of drinking water supply. During 1972-1986, the main focus was to provide safe and secure water to rural community by means of Public Health Engineering system [12]. In 1986, second generation Program was started with the launch of Technology Mission on Drinking Water and Related Water Management. And in 1991-1992, this technological mission renamed as Rajiv Gandhi National Drinking Water Mission (RGNDWM).Under this mission main emphasize was on water quality, new technology intervention, along with human resource development support and various other means for maintaining supply were introduced in Rural Water Supply sector. In 1999- Department of Drinking Water Supply (DDWS) was formed under the Ministry of Rural Development (MoRD).
(MoRD) to emphasize not only limited water supply but sanitation also. The third Generation Program started in 1999-2000 where new initiatives in water sector had been initiated through Sector reform projects which includes community participation in planning, implementation and management of water supply projects. In continuation to these schemes, new interventions scaled up as Swajaldhara in 2002. In the

Subsequent, fourth phase of Rural Water Supply Program main focus was on ensuring sustainability in availability of water in respect to convenience, adequacy, portability, equity and affordability [13]. National Rural Drinking Water Program(NRDWP) was launched in April 2009 by Department of Drinking Water and Sanitation ( presently Ministry of Drinking Water and Sanitation), for assisting states in providing drinking water to rural population of India [11]. Subsequently a program is initiated under Bharat Nirman UPA Government (which aimed at addressing water quality problem in all the affected habitation by 2009). The main aim of this program was to provide adequate and clean drinking water by means of hand pumps, piped water supply etc. to rural areas. This Program came into existence after merging three programs namely Accelerated Rural Water Supply Program (ARWSP); Swajaldhara and National Rural Water Quality Monitoring \& Surveillance.

This paper basically based upon Contingent Valuation Survey in order to determine the preferences of households for improved water facilities along with the amount they are willing to pay as well as Willingness to contribute in form of manual power so that people gets basic need of life in more effective way and also some amount of revenue is generated for the government authorities so that they can work in more efficient manner by making a sensible relation among the factors extracted by using Principal Component Analysis as extraction method followed by Varimax with Kaiser Normalization is used as rotation method from various variables used in this study which is further understood in the output section.

\section{BACKGROUND}

This study is conducted in the world's seventh largest country in terms of area [14], second most populous nation [15] and most populous democracy in the world i.e. India. India is a country situated in South Asia and located between $8^{\circ} 4^{\prime}$ and $37^{\circ} 6^{\prime}$ north latitude and $68^{\circ} 7^{\prime}$ and $97^{\circ} 25^{\prime}$ ' east longitude north of the equator [14]. Now, in terms of state, the present study is related to an area of a state which is the most populous having a population of $227,920,005$ as per 2011 census of India, which 


\section{Available online at www.ijrat.org}

happens to be Uttar Pradesh, situated in northern region of Indian subcontinent. Lucknow is the capital of Uttar Pradesh and state is divided into 18 divisions and 75 districts with total area of 243,290 $\mathrm{km}^{2}$ which is fourth largest area among Indian states. The present study is based on Bijnor which is one of the 75 districts present in Uttar Pradesh state. Location wise its latitude and longitude are 29.372442 and 78.135849 respectively, and is a part of Indo-gangetic alluvial plain. Its maximum length from east to west is about $90 \mathrm{~km}$ and north to south is about $102 \mathrm{~km}$ and having Moradabad as Administrative division. General data about district Bijnor- Area in Sq.km- 4,561, Density $/ \mathrm{km}^{2}-807$, Population-3,682,713, Population growth- $17.60 \%$, Proportion to Uttar Pradesh Population- $1.84 \%$, Sex Ratio ( Per 1000)- 917, Average Literacy- 68.48\%, Male Literacy- $76.56 \%$, Female Literacy- 59.72\%, Bijnor District Urban/Rural 2011- Out of total population, 25.13 percent lives in urban areas. Approximately, 925,312 people live in the urban region having and rest $74.87 \%$ population which is nearly 2757401 live in rural area. Religional aspects of Bijnor- There are mainly two religions Hindu $(55.18 \%)$ and Muslims (43.04\%) and rest include Sikh, Christian, Jain, and Buddhist [17].
Assembly Constituencies-Najibabad, Chandpur, Noorpur, Dhampur, Nagina, Bijnor, Barhapur and Nehtaur, total villages- 2,984 and total number of household- 631075. Study conducted on some villages of Bijnor suggests that the people of this area are not satisfied with the water system [16]. It is clear from above census report that majority of population live in rural areas of the district. If we talk about major source of income, the answer is Agriculture and the dominant crop is Sugarcane, followed by crops like Wheat, Paddy, Potato, Cereals etc. The main river of district is Ganga and next river comes is East Ramganga river. Some rivers of district include Ban, Khoh, Gangan, Karula, Malin, Chhoiya, Ekra, Pili, Dhara, Panili and Phika. In Bijnor- most of the irrigation practices are done by private tube well which means Ground water is main irrigation source and other sources include wells, ponds etc. Irrigation by government tube wells and canals is relatively lesser than other part of the state. About $1008 \mathrm{~mm}$ of precipitation falls in district annually with a monthly precipitation index of 43.074. Climate is sub humid with June as the hottest month and January being the coldest. Characteristic vegetation is grassland, having a normal annual wind speed of $6.7 \mathrm{Km} / \mathrm{hr}$. [18]. The political map of Uttar Pradesh with district Bijnor as study area is highlighted in Fig.1

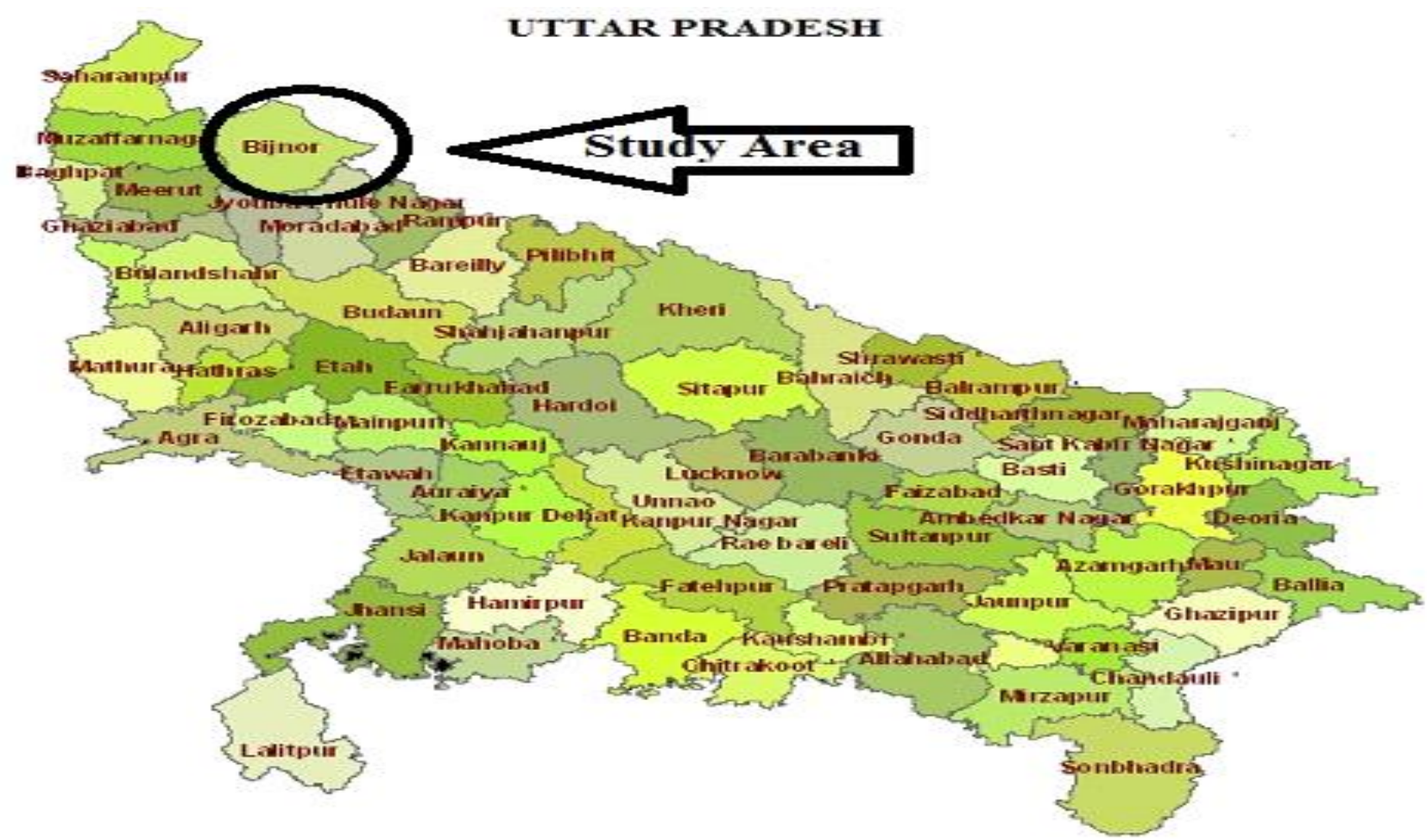

Fig.1- Political map of Uttar Pradesh. 
International Journal of Research in Advent Technology, Vol.6, No.9, September 2019

\author{
E-ISSN: 2321-9637 \\ Available online at www.ijrat.org
}

\section{METHODOLOGY USED}

\section{A. Data collection}

In this study, the data is collected by conducting survey in various villages of Bijnor District. For this purpose, first of all two categories were made 1) first category of villages in which there is supply of water by the Government agencies like UP Jal Board and 2) second category in which there is still no water supply by Government, therefore people are dependent on the groundwater sources like manually operated hand pumps and in some cases extracting water by means of electricity based hand pumps or submersible, which impart a huge burden on the groundwater of the region and is the main reason for depleting ground water table. The survey consists of a set of open ended questionnaire distributed to both category people, elected head of the village called as Gram Pradhan and other members of gram panchayat. Gram Pradhan gave basic necessary information about village like total population, total number of households, distance from main city, number of water connection, cost of water supply, mechanism to store or treat water, electricity supply and cost of electricity along with information regarding members of water committee and water system operator. Survey from village peoples consists of question related to gender of respondent along with its age, source of water, their educational and financial status along with number of members in the household, sanitation facilities, expenditure, as well as Govt. approach in the betterment of the village and a string of questions in relation to find out the main problem of villages in terms of water and sanitation. Study also consists of findings in form of Contingent Valuation Survey, which consists of questionnaire relating to peoples about their Willingness to contribute in terms of manual power for improved water supply along with some nominal charges for maintenance and operation of improved facilities in accordance to the water charges fixed by the govt. agencies. The survey was conducted to-find out the determinants for improved water supply, how many households are willing to contribute in terms of manpower and rent for improved supply, framing of policies for planning and cost recovery.

If we talk about period and duration of sampling, present study is conducted in near about 50-60 days. In order to get authentic results, only those houses were interviewed which were residing in the village before the water supply was introduced in that village, so that a clear vision of peoples towards water supply can be examined. Random sampling was done irrespective of gender, religion or age, it includes both male as well as female but emphasis was given to the household head to be interviewed along with persons of different age groups, in order to analyze the maximum views about the water system. In this process, 11 villages were covered and data of 10 households from each village was taken into consideration therefore we can say that 110 household is collected in the form of field work while keeping above mentioned factors into consideration.

\section{B. Processing of data}

Processing of data is performed by Factor Analysis tool in IBM "Statistical Package for the Social Sciences" (SPSS) Statistics Software [19]. It is a widely used software which demonstrated having importance in a large number of fields including educational, health, market, government organizations, data mines, survey companies and others. Original manual of SPSS describes SPSS as one of "sociology's most influential books" for allowing researchers to do statistical analysis apart from statistical analysis it has data documentation and data management as features of base software [20]. The importance of this software lies in the fact that it is capable to analyze data from almost every kind of format (e.g., binary, dollar, numeric, alphanumeric, time, date formats) and able to generate charts, tabulated reports and plots of trends and distribution, complex statistical and descriptive statistics analysis. It is highly used for iterative and non-iterative uses and has excellent data manipulation capability [21]. Factor Analysis tool was used for data processing in the present study and is one of the multivariate statistical methods of data reduction and leads to clear understanding of correlation among the observed variables, by determining the nature and number of common factors needed to establish a relationship among variables [22]. Factor analysis is really helpful to process a large sample size data as it removes duplication and redundancy among correlated variables and represents correlated variables along with derived variables. Tool is really helpful in describing many variables using few factors and is really beneficial in regression analysis.

In this study, we have used factor analysis for which Principal Component Analysis is used as the Extraction method, and Varimax with Kaiser Normalization is used for rotation of extracted data. Table 1 is Descriptive Statistics, which gives us basic information about variables in regard to their mean and standard deviation, it further shows maximum mean and standard deviation associated with income of the household and minimum in case of Willingness as labour means most of the village people are willing to contribute in terms of men power. 
International Journal of Research in Advent Technology, Vol.6, No.9, September 2019 E-ISSN: 2321-9637

Available online at www.ijrat.org

Table 1- Descriptive statistics

\begin{tabular}{|c|c|c|c|}
\hline & Mean & Std. Deviation & Analysis N \\
\hline Gender & 1.45 & .500 & 110 \\
\hline Education & 2.28 & 1.033 & 110 \\
\hline Family members & 8.7182 & 2.60251 & 110 \\
\hline Source & 2.16 & .862 & 110 \\
\hline Income & 135045.4545 & 108040.46017 & 110 \\
\hline Willingness as labour & 1.02 & .134 & 110 \\
\hline Fee 20/month & 1.54 & .501 & 110 \\
\hline Fee 30/month & 1.34 & .475 & 110 \\
\hline
\end{tabular}

Table 2- Correlation Matrix

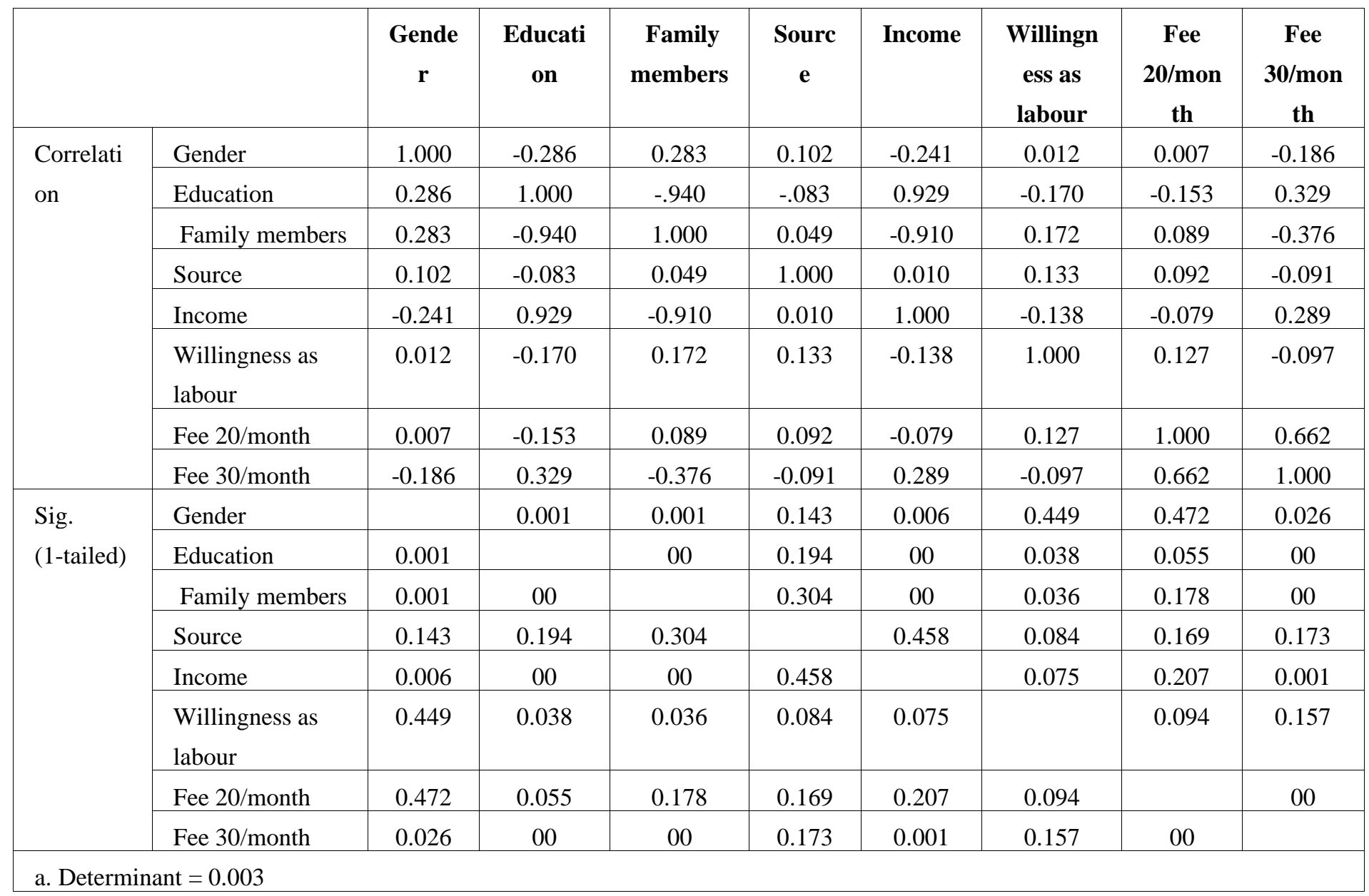




\section{International Journal of Research in Advent Technology, Vol.6, No.9, September 2019 E-ISSN: 2321-9637 \\ Available online at www.ijrat.org}

\section{RESULTS AND DISCUSSION}

After analyzing the above variables using Factor Analysis tool in IBM SPSS following results were obtained.

Table 2- is a correlation matrix which is used to show relationship among the variables. The upper half of table contains Pearson correlation coefficient among all pair of variables and lowers half consists of onetailed significance of these coefficient, determinant

Table 3- is very important as it gives idea about adequacy of sample given by Kaiser-Meyer-Olkin Measure, value greater than 0.5 is acceptable and our value 0.663 is more than 0.5 so, we can say factor analysis is appropriate for sample [24]. Another test i.e. Bartlett's test measures whether the original value at bottom of table is greater than 0.00001 signifies that multicollinearity issue in not associated with these data [23]. The above matrix is showing various relations but most important relation is that education is directly related to the income of the family, families having more income are willing to pay more for improved water supply and education having inverse relation with the number of family members.

correlation matrix is identity matrix or not, our significance value $(0.000)$ is less than 0.05 , which signifies that correlation matrix is not an identity matrix and Bartlett's test is highly significant so factor analysis can be done [25].

Table 3. KMO and Barlett's test

\begin{tabular}{|c|c|c|}
\hline Kaiser-Meyer-Olkin measure of sampling adequacy. & 0.663 \\
\hline $\begin{array}{c}\text { Bartlett's test of } \\
\text { sphericity }\end{array}$ & Approx. Chi-Square & 600.818 \\
\cline { 2 - 3 } & Df & 28 \\
\cline { 2 - 3 } & Sig. & 00 \\
\hline
\end{tabular}

Table 4 or output gives the Eigen values of each and every component before \& after extraction and after rotation. Eigen value basically represents the variance associated with that particular component and also representing Eigen value in terms of percentage of variance explained, second column in each stage. Before extraction there are 8 components in the dataset (as same as total components), it is clear that first few factors are showing more variance in respect to the subsequent factors. In extraction stage, 3 factors have been extracted having initial Eigen value greater than one, variance associated with these extracted factors are shown in Extraction Sums of Squared Loading. In Rotation Sums of Squared Loading, Eigen value associated with extracted factor after rotation is displayed. Rotation is done in order to equalize the relative importance of extracted factors.

Table 4. Total variance explained

\begin{tabular}{|c|c|c|c|c|c|c|c|c|c|}
\hline \multirow{2}{*}{$\begin{array}{c}\text { Com } \\
\text { pone } \\
\text { nt }\end{array}$} & \multicolumn{3}{|c|}{ Initial Eigen values } & \multicolumn{3}{|c|}{ Extraction sums of squared loadings } & \multicolumn{3}{|c|}{ Rotation sums of squared loadings } \\
\hline & Total & $\begin{array}{c}\% \text { of } \\
\text { Variance }\end{array}$ & $\begin{array}{l}\text { Cumula } \\
\text { tive } \%\end{array}$ & Total & $\begin{array}{c}\% \text { of } \\
\text { Variance }\end{array}$ & $\begin{array}{c}\text { Cumulative } \\
\%\end{array}$ & Total & $\begin{array}{c}\% \text { of } \\
\text { Variance }\end{array}$ & $\begin{array}{c}\text { Cumulati } \\
\text { ve } \%\end{array}$ \\
\hline 1 & 3.179 & 39.741 & 39.741 & 3.179 & 39.741 & 39.741 & 3.077 & 38.459 & 38.459 \\
\hline 2 & 1.627 & 20.337 & 60.078 & 1.627 & 20.337 & 60.078 & 1.662 & 20.776 & 59.235 \\
\hline 3 & 1.120 & 14.001 & 74.080 & 1.120 & 14.001 & 74.080 & 1.188 & 14.845 & 74.080 \\
\hline 4 & 0.957 & 11.968 & 86.048 & & & & & & \\
\hline 5 & 0.778 & 9.719 & 95.767 & & & & & & \\
\hline 6 & 0.216 & 2.695 & 98.462 & & & & & & \\
\hline 7 & 0.074 & 0.931 & 99.393 & & & & & & \\
\hline 8 & 0.049 & 0.607 & 100.00 & & & & & & \\
\hline
\end{tabular}

Table 5 shows communalities. Communalities denotes variance explained by the factors, in initial all variance are assumed to be common hence communalities are same before extraction. In 


\section{International Journal of Research in Advent Technology, Vol.6, No.9, September 2019 E-ISSN: 2321-9637 \\ Available online at www.ijrat.org}

extraction column values are showing common variance in data structure it interprets that $19 \%$ of variance associated with gender is common or shared variance or it is showing the individual variable's variance explained by factors retained after extraction.

Table 5- Communalities

\begin{tabular}{|c|c|c|}
\hline & Initial & Extraction \\
\hline Gender & 1.000 & 0.190 \\
\hline Education & 1.000 & 0.955 \\
\hline Family members & 1.000 & 0.942 \\
\hline Source & 1.000 & 0.695 \\
\hline Income & 1.000 & 0.923 \\
\hline Willingness as labour & 1.000 & 0.421 \\
\hline Fee 20/month & 1.000 & 0.907 \\
\hline Fee 30/month & 1.000 & 0.892 \\
\hline Extraction Method: Principal Component Analysis. & \\
\hline
\end{tabular}

Fig. 2 is Scree Plot graph and plotted between Eigen value and Component number and it shows inflexion point on the curve, it is another way to figure out how many factors has to be extracted, in this case three

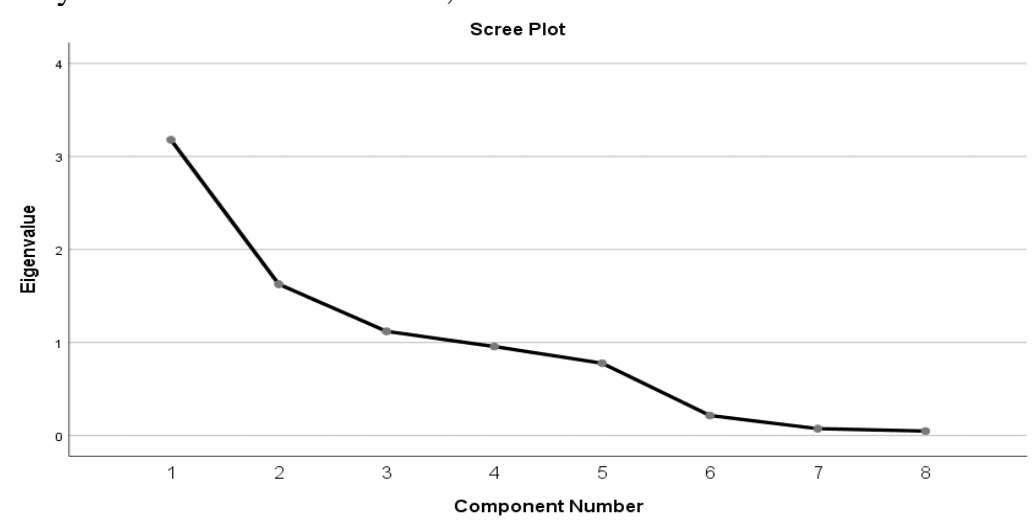

Fig.2-Scree Plot graph factors are retained after extraction as subsequent factors variance proportion is quite less as compared to the first three factors
Table 6 is Rotated Component Matrix or Rotated Factor Matrix showing correlation among factor and variables as well as variables weightage for each factor shown in Table 6. This is the most important result in interpreting the factor analysis. We may observe that factor 1 is highly correlated with variables education and income; we can say factor 1 is associated with development; factor 2 is related to Fee 20/month and 30/month somewhere showing Willingness to pay and in the same way factor 3 is correlated with source and Willingness as labour. 


\section{International Journal of Research in Advent Technology, Vol.6, No.9, September 2019 E-ISSN: 2321-9637 \\ Available online at www.ijrat.org}

Table 6- Rotated component matrix ${ }^{\mathrm{a}}$

\begin{tabular}{|c|c|c|c|}
\hline & \multicolumn{3}{|c|}{ Component } \\
\hline & 1 & 2 & 3 \\
\hline Gender & -0.352 & -0.138 & 0.216 \\
\hline Education & 0.973 & -0.003 & -0.093 \\
\hline Family members & -0.966 & -0.060 & 0.069 \\
\hline Source & 0.038 & -0.032 & 0.832 \\
\hline Income & 0.961 & 0.014 & 0.016 \\
\hline Willingness as labour & -0.151 & 0.070 & 0.627 \\
\hline Fee $20 /$ month & -0.144 & 0.929 & 0.155 \\
\hline Fee 30/month & 0.323 & 0.878 & -0.131 \\
\hline \multicolumn{4}{|c|}{$\begin{array}{l}\text { Extraction Method: Principal Component Analysis. } \\
\text { Rotation Method: Varimax with Kaiser Normalization. }{ }^{a} \\
\text { a. Rotation converged in } 4 \text { iterations. }\end{array}$} \\
\hline
\end{tabular}

\section{CONCLUSION}

By making a sensible relation among 3 factors discussed in Rotated Component Matrix, it can be concluded that education plays a vital role in the development of a human both economically as well as psychologically. Result indicates that the person who is educated earns more and willing to pay more for improved water supply. Household size is more for families which are lacking of proper education. Existing sources whether authorized agencies for water supply or other conventional sources are not fulfilling the water requirement of rural communities, challenges are not limited to provide water supply to those rural areas which still lacking of supply system but it is also associated with the dissatisfaction

\section{ACKNOWLEDGEMENT}

The authors wish to acknowledge Department of Civil Engineering, Bundelkhand Institute of Engineering \& Technology Jhansi and special thanks to people of villages along with elected head and members of gram panchayat for providing necessary information about the water supply system. This research did not receive any specific grant from funding agencies in the public, commercial, or not-for-profit sectors. reported among the people with the supply system provided. Authorities involved in management of rural water supply should be flexible enough so that they may find the issues related with the water supply like inappropriate hours of supply as well as fall in pressure of water after some distance. Villagers are not satisfied with the waters system and willing to contribute in terms of both manually as well as economically for the developed water system. Studies suggests that majority of people in the study villages are willing to pay a monthly Fee amount between 20 to 30 rupees per month for better water supply. So government can apply a fixed month charge which helps in revenue generation which can be utilized for maintenance of water supply system. 


\section{REFERENCES}

[1] Bibi, S., Khan, R. U., Nazir, R., Khan, P., Rehman, H. U., Shakir, S. K., Jan, R., Heavy Metals Analysis in Drinking Water of Lakki Marwat District, KPK, Pakistan. World Appl Sci J., 2016, 34(1), 15-19.

[2] Pawari, M. J. and Gawande, S. A., Ground water pollution \& its consequence, Int. j. Eng. Res.gen. sci., 2015, 3(4), 773-76.

[3] Montgomery, M.A. and Elimelech M., Water and sanitation in developing countries: including health in the equation, Environ. Sci. Technol., 2007, 41, 17-24.

[4] Khan, N., Husain, S.T., Saboor, A., Physiochemical investigation of the drinking water sources from Mardan, Khyber Pakhtunkhwa, Pakistan, Int. J. Phys. Sci., 2013, 8(33), 1661-71.

[5] Schweitzer, R. W. and Mihelcic, J. R., Assessing sustainability of community management of rural water systems in the developing world, J Water Sanit Hyg De, 2012, 2(1), 20-30.

[6] Kamble, S. M., Water pollution and public health issues in Kolhapur city in Maharashtra, Int J Sci Res, 2014, 4(1), 1-6.

[7] WaterAid India, WaterAid India Brochure. http://wateraidindia.in/our-impact/publications/page/7/

[8] Rijsberman, F.R., Water scarcity: Fact or fiction? Agric. Water Manage., 2006, 80 (1-3), 5-22.

[9] Mekonnen, M. M. and Hoekstra, A. Y., Four billion people facing severe water scarcity, Sci. Adv, 2016, 2(2), 1-6.

[10] The World Population Prospects: The 2017 Revision, published by UN Department of Economics and Social Affairs.

[11] Ministry of Drinking Water and Sanitation. https://swachhindia.ndtv.com/76-million-dont-have-safe-drinking-wat er-indias-looming-water-crisis-5606/[12]- Department of water supply and sanitation, Government of Punjab http://www.pbdwss.gov.in/dwss/left_menu/major_schemes_projects.h tml

[12] India water

portal, http://www.indiawaterportal.org/articles/national-rural-drinking-water -programme-framework-implementation-mord-2010

[13] Geography
https://en.wi https://en.wikipedia.org/wiki/Geography_of_India.

[14] Demographics https://en.wikipedia.org/wiki/Demographics_of_India

[15] Chauhan, D., Patel, N. and Srivastava, A., A statistical analysis of consumer satisfaction in rural water supply schemes: a case study of some villages of Bijnor District (Uttar Pradesh), India, Paripex-Indian Journal of Research, 2018, 7(9), 100-103.

[16] Bijnor District: Census 2011 data, http://www.census2011.co.in/census/district/505-bijnor.html.

[17] Budhauliya, A.K., Ground water brochure of Bijnor district, Uttar Pradesh, 2012-2013.

[18] Quintero, D., Ancel, T., Cassie, G., Ceron, R., Darwish, A., Felix, G., Pal, S., Workload optimized systems: Tuning POWER7 for analytics, IBM Redbooks, 2013.

[19] Wellman, M. P. and Hu, J., Conjectural equilibrium in multiagent learning. Machine Learning, 1998, 33(2-3), 179-200.

[20] Arkkelin, D., Using SPSS to understand research and data analysis, 2014.

[21] Conway, J. M. and Huffcutt, A. I., A review and evaluation of exploratory factor analysis practices in organizational research, Organ. Res. Methods., 2003, 6(2), 147-168.

[22] Yong, A. G. and Pearce, S., A beginner's guide to factor analysis: Focusing on exploratory factor analysis. Tutorials in quantitative methods for psychology, 2013, 9(2), 79-94.

[23] Kaiser, M. O., Kaiser-Meyer-Olkin measure for identity correlation matrix, J. Royal Stat. Soc, 1974, 52, 296-298.

[24] Williams, B., Onsman, A., Brown, T., Exploratory factor analysis: A five-step guide for novices, Aust. j. paramed., 2010, 8(3).

\section{AUTHORS PROFILE}

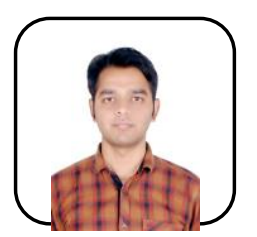

Deepak Chauhan has done M.Tech (Environmental Engineering) from BIET, Meerut. He has two international publications.

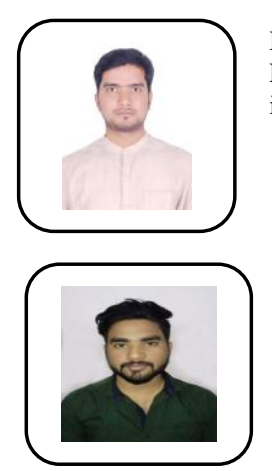

Dhananjai Rai has done M.Tech (Environmental Engineering) from BIET, Meerut. $\mathrm{He}$ has four international publications.

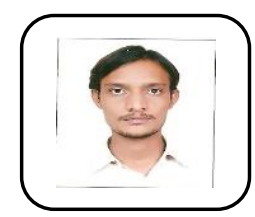

Naveen Patel has done M.Tech (Environmental Engineering) from NIT, Agartala. He has seven international publications.
MD. Zafar Ali Khan working as Guest Lecturer in Department of Civil Engineering at Gov. Polytechnic College, Gonda. $\mathrm{He}$ has one international publication. 